\title{
Local or Not? The Impact of Political System Factors on Media Election Coverage
}

\author{
Bengt Johansson ${ }^{1 *}$ and Erik Wettergren Mörtenberg ${ }^{2}$
}

${ }^{1}$ Department of Journalism, Media and Communication, Box 710, 40530 Göteborg, Sweden

${ }^{2}$ University of Gothenburg, Sweden

\begin{abstract}
This study aims to analyze the extent to whichpolitical system factors influence media election coverage by investigating the local election press coverage in Norway and Sweden. According to Hallin and Mancini's framework on media systems, both countries belong to the Democratic Corporatist Model. But despite these similarities there are differences between the politicaland media systems in the Nordic countries. One important distinction is when elections are held. In Sweden, elections to national, regional and local parliaments take place on the same day every fourth year. In Norway, local and regional elections are held in-between national elections in four-year cycles. The design of the study can be characterized as a most similar system design. Media system and the political system are similar, but when local/regional elections take place in relation to national elections are different. In line with theories of second-order elections, a number of hypotheses can be proposed, where national politics is supposed to be more influential in local election coverage in Norway compared with Sweden. This because research on second-order elections state that second order elections (such as local/regional elections) tend to be characterized as barometerelections, as a poll, evaluating the national government and how the development of national economy develops. The empirical analyses are based on a content analysis executed on four local newspapers in Norway and Sweden in the local elections in 2007 (Norway) and 2006 (Sweden) during the last two weeks of the election campaigns.
\end{abstract}

Keywords: Political System; Media; Election; Coverage; Democratic

\section{Introduction}

On Election Day the democratic principle of political equality most effectively comes into play [1]. Between elections, some people are more engaged and have more power and political resources than others, but on Election Day, each and every citizen has one and only one vote. But if citizens should to be able to make an informed decision they need information about the record of government and proposals for the future. In modern elections campaigns information of this kind is provided by the mass media, and therefore media coverage of elections is crucial in political systems characterized by mediated politics [2-4].

There is anextensive amount of studies of national election campaigns in media research. Ever since the classic study The People's Choiceby Lazarsfeld, Berelson and Gaudet in the 1940s, political scientists and media scholars have carried out content analyses to study the impact, newsworthiness and bias of election coverage [5-7]. These studies are usually cross-sectional, with one campaign analyzed in a single country $[8,7]$. However, there are examples of comparisons over time, [9-11] and there is a growing interest for cross-national studies [12-14].

Though, when performing comparisons between countries research design is mostly focused on national elections in countries quite different in terms of media and political system (most different system design), even if there are exceptions [15]. However, most different system designs areproblematic since there is not just one, but many aspects differentiating the countries compared.Consequently, it is difficult to draw conclusionsaboutthe impact of media or political system factors on news coverage. To be able to study effects of factors related to media systems or political systemsin a more stringent way, would be a most similar system design, where the impact of a single factor of media or political system can be isolated.

In the present study this design is used to determine whether differences in political systems will affect the election coverage. Norway and Sweden are to a large extent similar in terms of media system and political system [16]. But there is one important difference. In Sweden, elections to national, regional and local parliaments take place on the same day every fourth year. In Norway, local and regional elections are held in-between national elections in four-year cycles, which make it possible to analyze the extent to whichthis kind of dissimilarity has an impact on news reporting. This study aims to find out how political system factors influence the media election coverage, by analyzing the local/regional election press coverage in Norway and Sweden. Since the analysis raises comparisons between national and regional/local elections, the theoretical distinction between first and second-order elections will be used to deepen the understanding of media election coverage in the two countries.

\section{Norway and Sweden: two democratic corporatist countries}

Norway and Sweden are two countries which are quite similar. They are located next to each other in the northern part of Europe, have closely related languages and in many ways a common culture and history. In terms of media and politics they belong to what Hallin and Mancini [16] call the Democratic Corporatist model. Hallin and Mancini's work, which is empirically grounded, identifies three models of media and politics in Western democracies. These are of course

*Corresponding author: Bengt Johansson, Department of Journalism, Media and Communication, Box 710, 40530 Göteborg, Sweden, Tel: +46-31-786-4984; E-mail: bengt.johansson@jmg.gu.se

Received September 02, 2013; Accepted November 11, 2013; Published November 17, 2013

Citation: Johansson B, Mörtenberg EW (2013) Local or Not? The Impact of Political System Factors on Media Election Coverage. J Mass Communicat Journalism 3: 164. doi:10.4172/2165-7912.1000164

Copyright: (c) 2013 Johansson B, et al. This is an open-access article distributed under the terms of the Creative Commons Attribution License, which permits unrestricted use, distribution, and reproduction in any medium, provided the original author and source are credited. 
ideal types, but can be used to classify different countries and used as a framework for analysis [17].

When it comes to media systems, Hallin and Mancini identifies four important dimensions: (1) the development of media markets, especially the development of mass circulation press; (2) political parallelism, which refers to the relationship between the media and the political system (parties, political or social divisions in society), (3) the development of journalistic professionalism; and (4) the extent to which and in what way the state intervene in the media system. With regards to the political system Hallin and Mancini put emphasis on (1) political history, meaning patterns of conflict and consensus; (2) majoritarian government; (3) individual or organized pluralism; (4) the role of the state and state intervention in society; and the (5) the development of rational legal authority as opposed to clienteles [16].

As noted earlier Norway and Sweden are close to the ideal type of countries belonging to the Democratic Corporatistsystem. There is a long tradition of mass circulated press in both countries and especially a strong market for reading local daily newspapers [18]. There is a tradition of press owned by political parties, but these ties has weakened over time and journalistic professionalization has developed standards of impartiality in news reporting and news media independent of ownership [19]. In both countries, the widespread local press market is accompanied by a relatively strong public service broadcast tradition. Even if commercial broadcast media has gained significant market shares during the last decades, public service is still and important player in the national media system $[20,21]$. When it comes to the political system both countries are parliamentary democracies, with multi-party systems and proportional electoral systems. Another similarity is the domination of parties in relation to candidates. Even if there are possibilities to vote for a certain candidate, the parties have control over the nomination process and election campaigns are more focused on the struggle between parties than candidates [16].

Local, regional and national political levels in Norway and Sweden have a common structure concerning responsibilities and power. In general the national and local level is quite strong, while the regional level is comparatively weak. Most social services are governed by the municipalities, but some important issues are the responsibility of the regional political level. There are, however some differences in tasks carried out on different political levels between the countries. Health care is in Sweden a regional responsibility, but not in Norway where health care is the responsibility of state companies [22].

\section{Second-order elections and the media}

The distinction between first and second-order elections was made by the German political scientists Karlheinz Reif and Hermann Schmitt. Their comparative studies of elections to the European Parliament had a great impact and have been followed to a large number of analyses, especially on voting behavior [23,24]. In the literature a number of things are said to characterize second-order elections. Since these elections are seen as less important among elite actors, it becomes harder to mobilize voters. Voter turnout is therefore generally lower in second-order elections and as regards forEuropean parliamentary elections there are a steadily declining interest from the electorate. Another thing characterizing second-order elections are that election results predominantly is said to measure the popularity of national governments, rather than the issues that the elections actually applies. In European elections, it means that election campaigns tend to focus on domestic issues instead of issues that the EU Parliament to decide. Similarly, local elections taking place between national have the same kind of logic, where the debate focus on national issues and the election result also reflects the national government's popularity [25] Furthermore, smaller parties - often with populist and charismatic leaders - have a good chance to do well in the second-order elections. Protests and demonstrations of dissent with the current government favorparties of this kind. This is due largely to the major political parties' lack of resources and interest in campaigns [26]. Research on media coverage of second-order election indicatesa limited interest of the news media. Studies of the European parliamentary elections clearly showsa smaller news interest in comparison with national elections [14]. Research also indicates a stronger focus on domestic issues in the reporting, which mirrors a domestification rather than the Europeanization of campaigns [27]. Another aspect reflecting the relationship between first- and second-order elections is the extent to whichthe news focuses on candidates to the EU-parliament or other EU actors in relation to domestic political actors. Results show clearly that EU campaign news still predominately favors domestic politicians [27]. The analytic framework of second-order elections is dominated by research on comparing EU-parliament campaigns as second-order elections in relation to national first-order elections. There are however some studies comparing voting behavior which in many ways confirm local elections as second-order, even if not to the same extent as EU parliament elections [28]. Comparisons between local and national news coverage are even less explored, even if there are exceptions [29]. Media studiesfrom Sweden also indicate support for the secondorder election hypotheses, this since local elections receive less news coverage.But on the other hand local elections news emphasize on local issues and local political actors. In Norway, where studies of local election media coverage are rare, Jacobsen and Skomedal [30] show that local elections do receive a lot of attention, especially during the last weeks of the campaign [30]. However, no systematic study comparing newspapers in the two countries have been performed.

The conclusions discerned based on previous research, although discrepancies exist, may provide the basis for a number of hypotheses about the media coverage of second-order elections as local and regional elections in Norway and Sweden represents. But due to differences in the political system between the countries - in terms of separated or common Election Day, we should also find differences between the countries.

News evaluation is to a large extent a negotiation between different interests inside and outside the newsroom [31]. In a setting where local/regional and national elections are held simultaneously, we would expect to find different news evaluation compared with if elections campaigns take place separately. Since newspapers have a fixed number of pages and newscasts in broadcast media has limited airtime, decisions of newsworthiness of political news must be made in relation to the different election campaigns. We would therefore expect greater interest in local and regional elections in Norway compared withSweden in relation to national politics. This since the local and regional campaigns has to compete with the national election campaign in Sweden, which is not the case in Norway. The first hypothesis is therefore:

H1: Local and regional election campaigns receive more news attention in Norway compared with Sweden.

As earlier stated, second-order elections tend to be seen in relation to first-order elections. In European parliament elections this is shown by predominately news attention on domestic actors and issues. In line with this argumentation we should find the same tendencies in local/ regional election coverage. However, as pointed out earlier, this seems 
not the case.Empirical studies performed showed that local politicians dominatelocal election coverage-in both Norway and Sweden. But in relation to separate/common elections we might however find different levels of media attention of local politicians. The argumentation is as follows; the proportion of national politicians commenting local politics will be higher in Norway due to the fact that there is no national campaign taking place. In Sweden national politicians will to a larger extent focus on national issues, and the national campaign.

And since second-order elections in the literature predominantly can be seen as barometer-elections, we might expect the local coverage to focus on support/no support for the national government. The second and third hypotheses are therefore as follows:

$\mathrm{H}$ 2: Nationalpoliticiansare more frequentinlocal and regionalelection campaignsin Norwaythan in Sweden.

H3: News coverage of local and regional elections is more frequent about national political issues in Norway compared with Sweden

\section{Method}

To compare election news coverage of local electionstwo newspapers in each country was chosen which were considered functionallyequivalent. Selection criteriawerethat the newspaperwould bea medium-sizedlocal newspaper. The papers chosen were Fedrelandsvennen and Romerikes Bladfrom Norway and Borås Tidning and Skaraborgs Allehanda from Sweden. All newspapersare tabloidformatted and are the leading paper in their region.

The unit of analysis is single news articles and editorials during the last two weeks of the election campaign in Norway 2007 and 2006 in Sweden. All articles were manually selected and coded. Selection criterion was that the election should be in main focus of the article or politicians or parties being a dominant actor. This will broaden the perspective from articles explicitly focusing on the election, but during the last two weeks of an election campaign the frame is almost exclusively on the election, even if it's not always explicit.

In all the study includes 71 news articles and 7 editorials in Fedrelands-vennen, 81 news articles and 23 editorials from RomerikesBlad, 78 news articles and 29 editorials from BoråsTidning and 95 news articles and 8 editorials from SkaraborgsAllehanda. Since the election coverage on the on-line outlets of the newspapers was less extensive in 2006 and 2007, the decision was made not to include online outlets.

The code sheet included a number of variables. The most important variable measured if the article had a local, regional or national frame on politics. This was analyzed for news articles as for editorials. The frame was decided to what extent accountability and responsibility was addressed; in short is this seen as local, regional or national politics. In cases where more than one political level was addressed the most prominent was chosen. To capture dimensions of news attention variables such as the number of pictures and the amount of large-scale articles were used. The latter is defined as an article covering more than two-thirds of the page. To measure actors only the main political actor in the article were coded. Information in the article or additional information from websites of the municipalities was used to determine the political level of the politician (national, regional or local). To determine the most prominent issue in the article a variable were more than 30 different political issues could be coded.

To conduct an intracoder reliability check, 5 percent of the articles were randomly selected. Using Holist's formula [32] the reliability score was as lowest 0.90 (issue variable) and highest .93 (frame variable).

\section{Results}

The first hypothesis, about impact of political systems on media coverage, stated that local and regional elections would receive more attention in a country with separated elections. This was analyzed by contrasting a number of dimensions, all indicating different degrees of news value. The first one is the relationship between national and local/regional perspectives on politics in the news and on the editorial page of the newspaper. The second one analyze the number of news photos in the newspapers and the third the amount of large-scale news stories. The rationale is as follows; the more articles, pictures and largescale stories all indicate higher news value. In table 1-4, news about politics during election campaigns was analyzed in the dimensions described above. The results in Table 1 clearly show that local politics receive more news attention in the Norwegian newspapers, where 85 percent of all political news focuses on local politics. There is a stronger competition between different political levels in Swedish newspapers, where national election coverage is quite extensive even in local newspapers. Another thing worth mentioning is the low interest for regional election campaigns. In Sweden this tendency has been demonstrated in a number of studies [33]. But the results also show a limited interest from the media to cover regional election campaigns, even when national election is separated from local and regional elections. It seems like regional elections can be regarded as secondorder in relation to local elections or maybe even be characterized as third-order elections [26].

Moving on the editorials the difference between the two countries is even clearer (Table 1, column 2). When there is a joint election, the local newspapers put more emphasis on national politics. Only six percent of the editorials in Sweden focus on local politics. In Norway we find the opposite perspective. During local and regional elections the editorials predominately focus on local politics. The third dimension of news attention measures how often pictures are accompanying news articles, and the rationale is as follows; pictures are generally used to increase attention and can therefore be used as an indicator of news value. The results in Table 1, (column 3) showthe same tendencies as the previous. News photos are much more common in relation to local politics in the Norwegian papers compared with the Swedish. Again, the Swedish national election campaign receives extensive news attention.

\begin{tabular}{|c|c|c|c|c|}
\hline Norway & News & Editorials & News photos & $\begin{array}{l}\text { Large-scale } \\
\text { articles }\end{array}$ \\
\hline Local politics & 85 & 54 & 86 & 88 \\
\hline Regional politics & 7 & 25 & 7 & 5 \\
\hline National politics & 8 & 21 & 7 & 7 \\
\hline Percent & 100 & 100 & 100 & 100 \\
\hline$N=$ & 152 & 28 & 147 & 90 \\
\hline Sweden & News & Editorials & News photos & $\begin{array}{l}\text { Large-scale } \\
\text { articles }\end{array}$ \\
\hline Local politics & 54 & 6 & 54 & 53 \\
\hline Regional politics & 7 & 0 & 6 & 8 \\
\hline National politics & 39 & 94 & 40 & 39 \\
\hline Percent & 100 & 100 & 100 & 100 \\
\hline$N=$ & 173 & 36 & 129 & 83 \\
\hline Cramer's V & $.37^{* * *}$ & $.75^{\text {***}}$ & $.39^{* * *}$ & $.40^{* * *}$ \\
\hline
\end{tabular}

Note: ${ }^{*} p<0.05 .{ }^{* *} p<0.01{ }^{* * *} p<0.001$

Table 1: News, editorials, news-photos and large-scale articles about politics during local/regional election campaign in Norway 2007 and local/regional/national election campaign Sweden 2006 (percent). 
The fourth and last dimension of news attention is the number of large-sized articles. In addition to number of articles, news photos the proportion of large-sized articles can be seen as a measure of news attention, since newspapers generally judge newsworthiness by size. The results are consistent with the other dimensions (Table 1, column 4). The proportion of large-scale articles focusing on local politics is higher in Norway compared with Sweden.

We therefore can conclude that when local and regional elections are held separately from the national election local politics receivemore news attention. When elections are held simultaneously there is a stronger competition for news attention, and since local elections are second-order elections in relation to the national parliamentary election, we will in local newspapers find quite strong emphasis on national politics. One should also be aware of the fact that the newspapers cover a number of local elections. If BoråsTidningis taken as an example, the paper coverssevenmunicipalities andtherefore seven different local election campaigns.Thus the voter willreceive more information about the national election campaign in comparison with the local election he/she is entitled to vote in. $\mathrm{H} 1$ is therefore supported, but only in relation to local politics. Regional elections seem in terms of media coverage to be a third-order election.

The second hypothesis is more in line with second-order election theory in terms of analyzing the extent to which national politics is affecting the local campaign-measured how often national politiciansfunction as actors in local news.

The results in Table 2 confirm previous research; campaign coverage of local campaign is predominately an arena for local politicians. Even if the numbers are small we find the same tendency for regional elections. To conclude, we find that national politicians generally do not get much news attention in local elections independently of common or joint election days, and when national politicians receive news attention, they talk about national issues, not local.

But the hypothesis that national politicians will be more visible in local politics, when elections are held separately $(\mathrm{H} 2)$, also receives no support. Local politics in both countries are dominated by local politicians and even if the numbers of articles are small, the results

\begin{tabular}{|l|l|l|l|l|}
\hline Norway & Local politics & $\begin{array}{l}\text { Regional } \\
\text { politics }\end{array}$ & $\begin{array}{l}\text { National } \\
\text { politics }\end{array}$ & Cramer's V \\
\hline $\begin{array}{l}\text { Local/regional } \\
\text { politicians }\end{array}$ & 94 & 90 & 48 & $.48^{* * *}$ \\
\hline National politicians & 6 & 10 & 52 & \\
\hline Percent & 100 & 100 & 100 & \\
\hline $\mathrm{N}=$ & 126 & 10 & 12 & \\
\hline
\end{tabular}

Note: ${ }^{*} p<0.05 .{ }^{* *} p<0.01{ }^{* * *} p<0.001$

\begin{tabular}{|l|l|l|l|l|}
\hline Sweden & News & Editorials & News photos & $\begin{array}{l}\text { Large-scale } \\
\text { articles }\end{array}$ \\
\hline Sweden & Local politics & $\begin{array}{l}\text { Regional } \\
\text { politics }\end{array}$ & $\begin{array}{l}\text { National } \\
\text { politics }\end{array}$ & Cramer's V \\
\hline $\begin{array}{l}\text { Local/regional } \\
\text { politicians }\end{array}$ & 96 & 92 & 13 & $.83^{* * *}$ \\
\hline National politicians & 4 & 8 & 87 & \\
\hline Percent & 100 & 100 & 100 & \\
\hline $\mathrm{N}=$ & 92 & 12 & 62 & \\
\hline
\end{tabular}

Note: ${ }^{*} p<0.05 .{ }^{* *} p<0.01{ }^{* * *} p<0.001$

Table 2: Local and national politicians in news about politics during local/regional election campaign in Norway 2007 and local/regional/national election campaign in Sweden 2006 (percent).

\begin{tabular}{|l|l|l|l|}
\hline & Norway & Sweden & Cramer's V \\
\hline Local/regional government & 20 & 10 & .22 *** \\
\hline National government & 0 & 6 & \\
\hline Other issues & 80 & 84 & \\
\hline Percent & 100 & 100 & \\
\hline $\mathrm{N}=$ & 153 & 175 & \\
\hline
\end{tabular}

Note: ${ }^{*} \mathrm{p}<0.05 .{ }^{* *} \mathrm{p}<0.01{ }^{* * *} \mathrm{p}<0.001$

Table 3: News about local/regional and national government the local/regional election campaign in Norway 2007 and local/regional/national election campaign in Sweden 2006 (percent).

indicate that local politicians in Norway to a large extent comment national issues covered by the newspapers.

The third and last hypothesis concerns another aspect of secondorder elections theory. As stated earlier, European parliament election campaigns (as second-order elections) tend to focus on domestic issues instead of European perspectives. Support/lack of support for the national government seems also to be an important issue during second-order election, this since they tend to be a barometer of the sitting government.

In line second-order election theory we would expect more often find frames of national politics.But as seen it table 1this is not to be the case on a general level. Another way to capture tendencies of a "secondorder coverage" would be to measure how often news frames focus on the issue of government (local or national). If national politics affect the local media coverage we would expect to find news framed about support for the national government during the local and regional campaign in Norway.

As shown in Table 3, we donot find any tendency of this kind. Not a single news article in the Norwegian newspapers was framed on support or lack of support for the national government. When government is an issue, the frame is exclusively on the local or regional government, which can be about support or speculations about which parties will govern the region/municipality after the election. The third hypothesis (H3) is therefore rejected.

\section{Conclusions}

The present study was designed to test if differences in political systems will affect the election coverage. Norway and Sweden are to a large extent similar in terms of media system and political system. But local and regional elections are held simultaneously with national elections in Sweden and separately in Norway, this makes it is possible to analyze the extent to which this kind of dissimilarity have an impact on news reporting.

Theories of second-order elections were used as a theoretical framework for the analysis, this since local and regional elections can be seen as second-order in relation to national elections. The results both confirmed and rejected the stated hypotheses. In terms of news attention the hypothesis predicted more local/regional news about politics compared with national politics, when election days are separated. This hypothesis received clear support. The local papers in Norway almost exclusively cover local politics during the local and regional election campaign. However, using theoretical framework of second-order elections one could predict an impact of national perspectives in the coverage of local and regional election campaigns. However, these hypotheses were rejected. News reporting on national politics has its given place in local news Sweden when there is a joint election. But the prediction of an impact of national politics in the local reporting in Norway was not supported. Articles framed on 
national themes such as increased or decreased support for the national government was not found in the Norwegian newspapers and local and regional politicians were almost exclusively figuring as actors.

There is of course a need for more extensive comparative studies to ensure the findings. The rather independent coverage of local and to some extent regional election campaigns might not be found in other media like television or nationally circulated newspapers. Since agenda formation to a large extent is dependent on national media one would have to analyze national circulated media to better understand the relationship between political levels and news reporting.

One could also desire a more detailed analysis of the articles. There might be a more nuanced picture if sub-themes and more than one actor were coded. Even if the main perspective is local, we might find direct or indirect references to national politics if the articles were analyzed more in detail.

Anyhow, the conclusion of the present study is that political system do affects coverage. Separate elections will benefit more coverage of the local election. There will be more emphasis on the local election campaigns in both news and editorials. News photos and large-scale articles will also to a greater extent have a local campaign focus. Unlike coverage of EU election campaigns we find no evidence of first-order election perspective to take over the second-order election campaigns. As regards for Sweden, national, regional and local elections are of course competing for space more directly. But even so, the reporting of local and regional elections seems to be coverage on its own premises, and second-order elections do not necessarily therefore have to generate second-order coverage.

\section{References}

1. Dahl RA (1998) On Democracy. New Haven, Yale University Press.

2. Blumler JG, Gurevitch M (1995) The Crisis of Public Communication. London, Routledge.

3. Bennett WL, Entman RM (2001) Mediated politics: communication in the future of democracy. Cambridge, Cambridge University Press.

4. Farnsworth SJ, Lichter SR (2010) Trends in Television Network News Coverage of U.S. Elections. The Handbook of Elections News Coverage around the World. J. Strömbäck and L. L. Kaid. New York, London, Routledge.

5. GJ (2004) News Coverage of Political Campaigns. Handbook of Political Communcation Research. L. L. Kaid. Mahwah, New Jersey, Lawrence Erlbaum Associates.

6. Lange BP, Ward D (2004) Media and Elections: A Handbook and Comparative Study. New Jersey, Lawrence Erlbaum Associates.

7. Strömbäck J, Kaid LL (2010) Comparing Election News Coverage Around the World. The Handbook of Election News Coverage Around the World. J. Strömbäck and L. L. Kaid. New York London, Routledge.

8. Vreese CD (2003) Television reporting of second-order elections. Journalism Studies 4: 183-198.

9. Patterson TE (1993) Out of order. New York, Knopf.

10. Johansson B (2008) Popularized Election Coverage? News Coverage of Swedish Parliamentary Election Campaigns 1979-2006. Communicating Politics. Political Communication in the Nordic Countires. J. Strömbäck, M Ørsten.

11. Farnsworth SJ, Lichter SR (2010) Trends in Television Network News Coverage of U.S. Elections. The Handbook of Elections News Coverage around the World. J. Strömbäck and L. L. Kaid. New York, London, Routledge.

12. Strömbäck J, Dimitrova DV (2006) Political and Media system matter: A comparison of election news coverage in Sweden and the United States. Harvard International Journal of Press/Politics 11: 131-147.

13. Strömbäck J, Shehata A (2007) Structural bias in Britisch and Swedish election news coverage. A comparative study. Journalism Studies 8: 798-812.
14. Nord L, Strömbäck J (2008) Still a Second-Order Election: Comparing Swedish Media Coverage of the 2004 European Parliamentary Election and the 2002 National Election. The EU expansion: Communicating Shared Sovereignty in the Parliamentary Elections. L. L. Kaid. New York, Bern, Berlin, Bruxelles, Frankfurt am Main, Oxford, Wien, Peter Lang.

15. Strömbäck J, Aalberg T (2008) Election News Coverage in Democratic Corporatist Countries: A Comparative Study of Sweden and Norway. Scandinavian Political Studies 31: 91-106.

16. Hallin DC, Mancini P (2004) Comparing Media Systems. Three Models of Media and Politics. Cambridge, Cambridge University Press.

17. Strömbäck J, Kaid LL (2010) Comparing Election News Coverage Around the World. The Handbook of Election News Coverage around the World. J. Strömbäck and L. L. Kaid. New York London, Routledge.

18. Harrie E (2009) The Nordic Media Market 2009. Media Companies and Business Activities. Göteborg, Nordicom.

19. Eide M (2009) Journalistiske nyorienteringer. Oslo, Scandinavian Academic Press.

20. Syvertsen T (1997) Den store TV-krigen. Norsk allmennfjernsyn 1988-96. Oslo, Fagbogforlaget.

21. Djerf-Pierre M, Weibull L (2001) Spegla, granska, tolka: aktualitetsjournalistik i svensk radio och TV under 1900-talet. Stockholm, Prisma.

22. Lidström A (2003) Kommunssystem i Europa. Stockholm, Liber.

23. Reif, Sandberg S (2009) Västra Götalandsregionen och det svenska regionidealet i nordisk belysning. Att bygga, att bo, att leva. L. Nilsson and S. Johansson. Göteborg, Göteborgs universitet. SOM-instiutet.

24. Eijk CVD, Franklin M (1996) Choosing Europe? The European Electorate and National Politics in the face of Union. Michigan, Ann Arbor, University of Michigan Press.

25. Oscarsson H, Holmberg S (2006) Europaval, Göteborgs universitet: Statsvetenskapliga institutionen.

26. Norris P (1997) Second-order elections revisited. European Journal of Political Research 31: 109-114

27. Vreese CD (2007) The Media and European Parliament Elections: Second Rate Coverage of a Second-Order Event? European Elections and Domestic Politics: Lessons from the Past and Scenarios for the Future. W. v. d. Brug and C. v. d. Eijk. Notre Dame, Indiana, University of Notre Dame Press.

28. Rallings C, Thrasher M (2005) Not All 'Second-Order' Contests are the Same: Turnout and Party Choice at the Concurrent 2004 Local and European Parliament Elections in England. British Journal of Politics \& International Relations 7: 584-597.

29. Oscarsson H (2001) Skilda valdagar och vårval.

30. Jacobsen DI, Skomedal AS (2009) Regional Newspaper Coverage of Norwegian Local Elections: Election Coverage in the Agderposten and Fedrelandsvennen Newspapers. The World Political Science Review 5: 1.

31. Shoemaker PJ, Reese SD (1996) Mediating the Message: Theories of Influence on Mass Media Content. New York, Longman.

32. Holsti OR (1969) Content Analysis for the Social Sciences and Humanities. Reading, MA, Addison Wesley.

33. Johansson B (2010) I skuggan av riksdagsvalet. Lokala medievalrörelser och andra rangens val. Kommunala valrörelser 2006. F. Johansson. Goteborg, Göteborgs universitet. 